\title{
Premarital sexual practice and associated factors among high school youths in Debretabor town, South Gondar zone, North West Ethiopia, 2017
}

\author{
Wondmnew Lakew Arega', Taye Abuhay Zewale ${ }^{2 *}$ and Kassawmar Angaw Bogale ${ }^{3}$
}

\begin{abstract}
Objective: Premarital sex is voluntary sexual intercourse between unmarried persons. Prevalence and factors associated with premarital sexual practice in the study area are lacking. Thus, the aims of this study were to determine the prevalence and to identify factors associated with premarital sexual practice among Debretabor high school youths.

Results: The prevalence of premarital sex among Debretabor town high school youths was 22.5\% of which 63.9\% of them were males. Among those high school youths, the majority (60.2\%) had their first sexual intercourse at the age of 15-19 years. The main reason for initiation of sexual intercourse was due to fell in love which accounts $48.1 \%$, followed by sexual desire $22.2 \%$. Predictors that are risk for premarital sex were youths who did not attend religious education $[A O R=7.4,95 \% \mathrm{Cl}(3.32,16.43)]$, having boy or girl friends $[\mathrm{AOR}=9.66,95 \% \mathrm{Cl}(4.80,19.43)]$, drinking alcohol every day $[A O R=9.43,95 \% \mathrm{Cl}(2.86,31.14)]$ and less than twice a week $[A O R=2.52,95 \% \mathrm{Cl}(1.22,5.21)]$, watching pornography film $[\mathrm{AOR}=5.15,95 \% \mathrm{Cl}(2.56,10.37)]$ and youths came from rural residing families $[\mathrm{AOR}=0.51,95 \% \mathrm{Cl}$ $(0.27,0.96)]$.
\end{abstract}

Keywords: Premarital sex, Youths, Debretabor, Ethiopia

\section{Introduction}

Youths are in a state of rapid physical and psychological change. They have curiosity and urge to experience new phenomena [1]. Nevertheless, youths are exposed to different circumstance like fears, worries and different desires, they feel shame to get advice and guidance from their parents and elders [2]. Over a life cycle approach, youths and their communities need to know about reproductive health so that, they can make informed decisions about their reproductive health and sexuality $[3,4]$. Premarital sex, defined as voluntary sexual intercourse between unmarried persons, is increasing worldwide [5]. It is unsafe because, most youths have no enough

\footnotetext{
*Correspondence: tabu0918@gmail.com

2 Department of Epidemiology and Biostatistics, School of Public Health, College of Medicine and Health Sciences, Bahir-Dar University, Bahir Dar, Ethiopia

Full list of author information is available at the end of the article
}

awareness on how to prevent and how to get guidance services on reproductive anatomy, physiology, sexually transmitted infection (STI), and Human Immunodeficiency Virus (HIV) [6, 7]. As a result, they are exposed to serious problems including premarital sex with its consequences and emotional scar $[8,9]$.

Though, schools are institutions where sufficient information and formal educations are provided to youths, premarital sexual practice among high school youths have been increased worldwide [10]. Globally, 35.3 million people live with HIV/AIDS of which youths account 2.1 million. Among 2.3 million new HIV infections, youths (15-24 years) account more than half [7].

Illegal abortions, risk of HIV infections and school dropout are the bad consequences of pre-marital sex in sub-Saharan Africa [11]. Up to 25\% of 15-19 years, old youth's exercised sex before age 15. In Ethiopia, the prevalence of premarital sex is increasing [12-14]. A study conducted in Eastern part of Ethiopia and Lalibela Town 
reported that above one-fourth of the school youths were exposed to premarital sex $[12,15]$. Another study which is done in west Shoa Zone reported that about $60 \%$ of high school youths were exercised premarital sex [9]. Different scholars identified inconsistent factors which were positively or negatively associated with premarital sexual practice. Some of these factors includes age of students, sex, residence, educational level, peer pressure, having pocket money, substance use, alcohol drink, watching pornography movie, living arrangement, discussion with parents about sexual issues, having peers who are experienced sex and fall in love and access religious and life skill education [9, 12-17].

According to Debretabor district health office report sexually transmitted diseases, abortion and unwanted pregnancy are high in the study area among youths [18]. However, prevalence of premarital sexual practice and its associated factors among high school youths (grade 9th to grade 12th) in the study area was not dealt yet. Thus, this study aimed to determine premarital sexual practices and associated factors among high school youths in Debretabor town, south Gondar, Ethiopia.

\section{Main text \\ Methods}

\section{Study design and setting}

School based cross-sectional study design was conducted from September 18 to October 16, 2017, among high school youths in Debretabor town, South Gondar zone, Ethiopia. Debretabor town is located at $667 \mathrm{~km}$ from Addis Ababa, capital city of Ethiopia and has three high schools. The total numbers of high school youths in the study area by the year 2017 were 8892 (5220 females and 3672 males) [18].

\section{Source population}

The source population was all high school youths who were residing in Debretabor town and its surrounding rural Kebeles.

\section{Study population}

The study population was all high-school youths aged 15 to 24 years that were enrolled as a regular day-time student in 2017.

\section{Inclusion criteria}

All secondary school youths aged 15-24 attending regular class in Debretabor town during data collection period were included in the study.

\section{Exclusion criterion}

Married high school youths were excluded.

\section{Sample size determination}

Sample size was calculated using a single population proportion formula designated as $\mathrm{n}=\frac{\left(Z_{\alpha / 2)}^{2} p(1-p)\right.}{d^{2}}$ based on the assumptions of $P$-value $=0.25$ which was the proportion of premarital sex among in-school youths in Jimma [19], a 95\% confidence level, 4\% margin of error (d) and $10 \%$ non-response rate. Accordingly, the total sample size calculated was 497 .

\section{Sampling procedure}

All the high schools in the town were included in the study, and total sample size was proportionally allocated to each school. The lists of youths were obtained from the respective school registrar. Then, the study participants from each school were selected by computer generated simple random sampling technique after proportional allocation to their grade level.

\section{Data collection}

Pre-tested, self-administered structured Amharic (local language) questionnaire was used to collect the data. The questionnaire was pre-tested on $10 \%$ of the study participants at Alem-ber high school, which has the same setup to the study area, found in South Gondar zone. The questionnaire was amended according to the finding in the pretest before the distributions of final questionnaires. Training was given for data collectors and supervisors. Before the participants filled the questionnaires, the trained data collector gave orientation to youths regarding the aim of the study, the content of the questionnaire, the issue of confidentiality and respondents rights. Moreover, trained data collectors were involved in taking consents from participants and gathering filled questionnaires. However, data collectors were not present when the participants were filling the questionnaire.

The study used premarital sex practice as dependent variable and Socio-demographic Characteristics of youths and parents (age, sex, education level, religion, pocket money living arrangement, parental education, parental occupation, sexual issue discussion with parents), risk behavior and peer pressure (chat chewing, alcohol drinking, cigarette smoking, watching pornography, Peer friend initiation of sex) and history of partner hood, demand for condom utilization (number of partners, having the boy/girlfriend, condom utilization) as independent variable.

\section{Data management and analysis}

The data were entered using Epi-info version 7.2.1 and exported to SPSS version 23 for analysis. Descriptive statistics like frequency, percentage and standard deviation was computed. Binary logistics regression model was 
applied to identify determinant factors related premarital sexual practice. Variables with $P$ value less than 0.25 on bi-variate analysis were entered to multi-variate analysis. 95\% confidence interval was used to identify associated factors in multi-variable binary logistic regression model. Hosmer-Lemeshow goodness of the model fit was checked and analysis was done by entering procedure.

\section{Result}

Socio-demographic characteristics of the respondents

Four hundred eighty high school youths were filled the questionnaire making a response rate of $96.6 \%$. From the total respondents, more than half $(53.8 \%)$ of them were females. Majority (71.2\%) youths age were from 15 to 19 years. The average age and standard deviation of respondents were 17 and 1.29 years respectively. Larger proportion (35.8\%) of the participants were grade nine students. The majority (97.5\%) of the respondents were Orthodox Christians. Only 23.3\% of in school youths had pocket money, about $89 \%$ of youths were living with their parents and attending religious services. Moreover, above half (61\%) of the youths didn't discuss about sexual issues with their parents (Table 1).

\section{Sexual characteristics and risk behavior of respondents}

From all respondents, 22.5\% have had premarital sexual intercourse at the time of the survey, of which $63.9 \%$ were males and $60.2 \%$ had their first sexual intercourse at the age of 15-19 years. The main reason for initiation of sexual intercourse was due to fell in love which accounts $48.1 \%$, followed by sexual desire $22.2 \%$.

Concerning the number of sexual partners, majority $(84.3 \%)$ of students have had sex with one partner and about $58 \%$ of the them were used condom during sexual intercourse. Coming to risky behavior, $28.1 \%$ of the youths drunk alcohol, $16.2 \%$ watched pornography and $2.7 \%$ chewed khat. About $61 \%$ of youths who watched pornography film were exposed to premarital sex (Table 2).

\section{Factors associated with premarital sexual practice among high school youths in Debretabor town, 2017}

The Logistic regression analysis showed that premarital sexual practice among youths who did not attend religious education was 7.4 times more likely exposed to premarital sex as compared to the counterpart $[\mathrm{AOR}=7.4$, 95\% CI $(3.32,16.43)]$. Similarly, youths who had a boy or a girl friend were 9.66 times more likely to start premarital sex than those who didn't have a boy or a girl $[\mathrm{AOR}=9.66,95 \% \mathrm{CI}(4.80,19.43)]$. Youths who were drinking alcohol every day and less than twice a week were 9.43 times $[\mathrm{AOR}=9.43,95 \% \mathrm{CI}(2.86,31.14)]$ and 2.52 times $[\mathrm{AOR}=2.52,95 \% \mathrm{CI}(1.22,5.21)]$ more likely
Table 1 Socio-demographic characteristics of high school youths in Debretabor town, South Gondar, Amhara Regional State, 2017

\begin{tabular}{|c|c|c|}
\hline Variables & Frequency & Percent \\
\hline \multicolumn{3}{|l|}{ Sex } \\
\hline Male & 222 & 46.2 \\
\hline Female & 258 & 53.8 \\
\hline \multicolumn{3}{|l|}{ Residence } \\
\hline Rural & 239 & 49.8 \\
\hline Urban & 241 & 50.2 \\
\hline \multicolumn{3}{|l|}{ Age } \\
\hline $13-17$ & 342 & 71.2 \\
\hline $18-24$ & 138 & 28.8 \\
\hline \multicolumn{3}{|l|}{ Grade } \\
\hline Grade 9th & 172 & 35.8 \\
\hline Grade 10th & 156 & 32.5 \\
\hline Grade 11th & 90 & 18.8 \\
\hline Grade 12th & 62 & 12.9 \\
\hline \multicolumn{3}{|l|}{ Religion } \\
\hline Orthodox & 468 & 97.5 \\
\hline Muslim & 1 & 0.2 \\
\hline Protestant & 6 & 1.3 \\
\hline Catholic & 5 & 1.0 \\
\hline \multicolumn{3}{|c|}{ Do you attending religious services? } \\
\hline No & 53 & 11 \\
\hline Yes & 427 & 89 \\
\hline \multicolumn{3}{|c|}{ Do you ever discussed about sexual issue with parents? } \\
\hline Yes & 187 & 39 \\
\hline No & 293 & 61 \\
\hline \multicolumn{3}{|c|}{ Do you have pocket money? } \\
\hline Yes & 112 & 23.3 \\
\hline No & 368 & 76.7 \\
\hline \multicolumn{3}{|c|}{ With whom do you live now? } \\
\hline Alone & 25 & 5.2 \\
\hline With parents & 428 & 89.2 \\
\hline With friends/relatives & 27 & 5.6 \\
\hline
\end{tabular}

engaged in premarital sex practice respectively as compared to those who did not drink alcohol. Students who watched pornography film were 5.15 times more likely practiced premarital sex as compared to those who didn't watch pornography film $[\mathrm{AOR}=5.15,95 \% \mathrm{CI}(2.56$, 10.37)]. But it was found to be less likely among urban youths resident family as compared with youths who came from rural resident families (Table 3).

\section{Discussion}

Premarital sexual practice of high school youths in this study was $22.5 \%$ (CI: 19.0, 26.5). This finding was in line with a study conducted in Nekemtie town (21.5\%) [20], in 
Table 2 Sexual history and risky behavior of high school youths in Debretabor town, South Gondar, Amhara regional State, 2017

\begin{tabular}{|c|c|c|}
\hline Variable & Frequency & Percent \\
\hline \multicolumn{3}{|c|}{ Did your peer friends experienced with sexual intercourse? } \\
\hline Yes & 56 & 11.7 \\
\hline No & 424 & 88.3 \\
\hline \multicolumn{3}{|c|}{ Did your peer friend initiate you sexual intercourse? } \\
\hline Yes & 41 & 8.5 \\
\hline No & 439 & 91.5 \\
\hline \multicolumn{3}{|c|}{ Have you ever chewing chat? } \\
\hline Yes & 13 & 2.7 \\
\hline No & 467 & 97.3 \\
\hline \multicolumn{3}{|c|}{ Have you ever drink alcoholic beverage? } \\
\hline Yes & 135 & 28.1 \\
\hline No & 345 & 71.9 \\
\hline \multicolumn{3}{|c|}{ Have you ever smoke cigarette? } \\
\hline Yes & 8 & 1.7 \\
\hline No & 472 & 98.3 \\
\hline \multicolumn{3}{|c|}{ Have you ever watched sex film? } \\
\hline Yes & 78 & 16.2 \\
\hline No & 402 & 83.8 \\
\hline \multicolumn{3}{|c|}{ Do you have boy/girl friend? } \\
\hline Yes & 108 & 22.5 \\
\hline No & 372 & 77.5 \\
\hline \multicolumn{3}{|c|}{ Have you ever had premarital sexual intercourse? } \\
\hline Yes & 108 & 22.5 \\
\hline No & 372 & 77.5 \\
\hline \multicolumn{3}{|c|}{ Reason to have sex } \\
\hline Love & 52 & 48.1 \\
\hline Sexual desire & 24 & 22.2 \\
\hline Peer pressure & 15 & 14.0 \\
\hline Chance & 17 & 15.7 \\
\hline \multicolumn{3}{|c|}{ Did you use condom when you had sex $(n=108) ?$} \\
\hline Yes & 63 & 58.3 \\
\hline No & 45 & 49.7 \\
\hline \multicolumn{3}{|c|}{ Did you use any contraceptive methods $(n=108)$ ? } \\
\hline Yes & 44 & 40.7 \\
\hline No & 64 & 67.3 \\
\hline \multicolumn{3}{|c|}{ Have you ever been pregnant $(n=39) ?$} \\
\hline Yes & 8 & 20.5 \\
\hline No & 31 & 79.5 \\
\hline \multicolumn{3}{|c|}{ How many sexual partners do you have so far $(n=108) ?$} \\
\hline One & 91 & 84.3 \\
\hline Two & 17 & 15.7 \\
\hline
\end{tabular}

Jimma (21\%) [19] and school youths in Alamata (21.1\%) [21]. However, it was higher than in Coast Province, Kenya youths (14.9\%) [22], and Robit high school youths (14.9\%) [10]. The difference might be as a result of sample size, coast province; Kenya used existing data available from
Kenya Global School Based Health Survey (GSHS) which was national study. So it could be more precise as compared with this study. In addition, there might be sociocultural differences in community among study areas.

But this finding was lower than in-school youths in Ghana (42\%) [23], in Jimma (28.5\%) [24] in Eastern Ethiopia (24.8\%) [12] and in Debremarkos high school youths (37.5\% [25]. The variation may be due to difference in periods of the study (2011-2014), showing a changing and improving trend in easiness of reporting sexual matters and increasing premarital sexual awareness from time to time $[7,26]$. The difference might also be due to variations on the prevalence of risky sexual behavior.

This study also found that those youths who didn't attend religious education were more likely exposed to premarital sex as compared with their counter parts. It is in agreement with studies conducted in Bahir Dar City [14] and Mizan Aman [27]. The possible reason could be religious institutions strongly thought youths to be abstained until marriage.

High School youths who have a boyfriend or girlfriend were more likely to have premarital sexual intercourse than those who don't. There were similar reports in Alamata [28], and Nekemt towns [20]. This could be due to the pressure from their boy/girl friend to have sexual practice.

Youths who drunk alcohol were engaged in premarital sexual practice as compared to their counterparts. This finding is the same as the studies done in South West [27] and Western Ethiopia [29]. The possible explanation might be, when youths drink alcohol, his/her ability of self-controlling decrease and this may expose to premarital sex.

Students who watched pornography film were more likely practiced premarital sex as compared to those who didn't. There is similar finding in Shendi Town [13] and Northern Ethiopia [7]. The possible reason could be pornography film leads youths physiological and psychological motive for sexual intercourse.

Youths from rural family residents were more exposed to premarital sex urban youths. This is not in agreement with other studies $[7,21,28,30,31]$. This difference might be due to low parental control of rural youths as they lived with rented rooms, exposed to exercising sexual issues freely.

\section{Conclusions}

Significant numbers of high school youths were engaged in sexual practice before marriage. Not attending religious education, have a boy/girlfriend, watching pornography film, alcohol drinkers and came from rural residing families were identified risk factors. So, the school community and respective health sector need to establish and strengthen school health program and school clubs to 
Table 3 Factors associated with premarital sex of high school youths in Debretabor town, South Gondar, 2017

\begin{tabular}{|c|c|c|c|c|c|}
\hline \multirow[t]{2}{*}{ Variable } & \multicolumn{2}{|c|}{ Premarital sex } & \multirow[t]{2}{*}{ COR $(95 \% \mathrm{CI})$} & \multirow[t]{2}{*}{ AOR (95 Cl) } & \multirow[t]{2}{*}{ P-value } \\
\hline & Yes & No & & & \\
\hline \multicolumn{6}{|l|}{ Sex } \\
\hline Male & 153 (69\%) & $69(21 \%)$ & 1 & 1 & \\
\hline Female & $219(85 \%)$ & $39(15 \%)$ & $0.39(0.25,0.61)$ & $0.81(0.43,1.52)$ & 0.51 \\
\hline \multicolumn{6}{|l|}{ Age } \\
\hline $15-19$ & $273(80 \%)$ & 69 (20\%) & 1 & 1 & \\
\hline $18-24$ & $99(72 \%)$ & $39(28 \%)$ & $1.55(0.98,2.45)$ & $1.39(0.71,2.70)$ & 0.34 \\
\hline \multicolumn{6}{|l|}{ Residence } \\
\hline Rural & $172(72 \%)$ & $67(28 \%)$ & 1 & 1 & \\
\hline Urban & $200(83 \%)$ & $41(17 \%)$ & $0.52(0.33,0.81)$ & $0.51(0.27,0.96)$ & 0.04 \\
\hline \multicolumn{6}{|l|}{ Live with whom } \\
\hline Alone & $13(52 \%)$ & $12(48 \%)$ & 1 & 1 & \\
\hline Parent & $338(79 \%)$ & 90 (21\%) & $0.28(0.12,0.65)$ & $0.44(0.14,1.37)$ & 0.0 .16 \\
\hline Friends & $21(78 \%)$ & $6(22 \%)$ & $0.31(0.09,1.0)$ & $0.73(0.14,3.78)$ & 0.70 \\
\hline \multicolumn{6}{|l|}{ Pocket money } \\
\hline Yes & $73(65 \%)$ & $39(35 \%)$ & 1 & 1 & \\
\hline No & 299 (81\%) & 69 (19\%) & $0.43(0.27,0.69)$ & $0.82(0.42,1.62)$ & 0.57 \\
\hline \multicolumn{6}{|c|}{ Attending religious education } \\
\hline Yes & $349(82 \%)$ & $78(18 \%)$ & 1 & 1 & \\
\hline No & $23(43 \%)$ & $30(57 \%)$ & $5.83(3.21,10.59)$ & $7.4(3.32,16.43)$ & 0.00 \\
\hline \multicolumn{6}{|c|}{ Discussed about sexual issue with parents } \\
\hline Yes & $136(73 \%)$ & $51(27 \%)$ & 1 & 1 & \\
\hline No & $236(81 \%)$ & $57(18 \%)$ & $0.64(0.41,0.99)$ & $0.49(0.20,1.18)$ & 0.115 \\
\hline \multicolumn{6}{|l|}{ Peer friend initiate you } \\
\hline Yes & $20(49 \%)$ & $21(515)$ & 1 & 1 & 1 \\
\hline No & $352(80 \%)$ & $87(20 \%)$ & $0.23(0.12,0.45)$ & $0.97(0.2,3.47)$ & 0.969 \\
\hline \multicolumn{6}{|c|}{ Do you have boy/girl friend } \\
\hline Yes & $93(43 \%)$ & $124(57 \%)$ & & 1 & \\
\hline No & $15(6 \%)$ & $248(94 \%)$ & $12.40(6.89,22.28)$ & $9.66(4.80,19.43)$ & 0.000 \\
\hline \multicolumn{6}{|l|}{ Pornography watching } \\
\hline Yes & $44(61 \%)$ & $28(39 \%)$ & $9.13(5.27,15.81)$ & $5.15(2.56,10.37)$ & 0.00 \\
\hline No & $59(15 \%)$ & $343(85 \%)$ & 1 & 1 & \\
\hline \multicolumn{6}{|c|}{ Have you ever drink alcoholic beverage } \\
\hline Never & $283(85 \%)$ & $49(15 \%)$ & 1 & 1 & 1 \\
\hline Less than twice a week & $63(66 \%)$ & $32(34 \%)$ & $2.93(1.74,4.94)$ & $2.52(1.22,5.21)$ & 0.01 \\
\hline Twice a week & $19(59 \%)$ & $13(41 \%)$ & $3.95(1.83,8.51)$ & $2.67(0.99,7.21)$ & 0.053 \\
\hline Everyday & $7(33 \%)$ & $14(67 \%)$ & $11.55(4.43,30.06)$ & $9.43(2.86,31.14)$ & 0.000 \\
\hline
\end{tabular}

give awareness about identified risks of premarital sex. In addition family should link their youths to religious education in parallel to formal school education.

\section{Limitation of the study}

Since the nature of this study is sensitive, reporting errors and biases can't be controlled. In addition as this study used only quantitative data, the behavioral related information might be missed. Since the questionnaire was self-administered, lack of control over the responses rate, no control over who filled the questionnaires and questions may be miss-understood so that the true impression of the participants may not be gathered.

\section{Abbreviations}

AIDS: Acquired Immune Deficiency Syndrome; AOR: adjusted odds ratio; Cl: confidence interval; EC: Ethiopian calendar; DHS: Demographic Health Survey; EDHS: Ethiopia Demographic Health Survey; SD: standard deviation; BSC: Bachelor of Science; HIV: Human Immunodeficiency Virus; MPH: Masters of Public Health; SPSS: Statistical Package for Social Science; STI: sexually transmitted infection; WHO: World Health Organization; GSHS: Global School Based Health Survey. 


\section{Acknowledgements}

The researchers would like to thank Bahir-Dar University, College of Medicine and health Science for permitting to conduct this research and Debretabor town education offices and the respective staffs for providing the required information on time and their cooperativeness for the study. At last but not least, our gratefulness thanks go to the data collectors and the study participants.

\section{Authors' contributions}

WLA conceptualization of the study, designed the study, collected data, drafts the analysis, interpreted the data and drafts the manuscript. TAZ designs the work, enter the data and analyze using software, interpretation of results as well as critical review of the manuscript. KAB Participated in design the study, drafting the manuscript and subsequent review of the manuscript. All authors read and approved the final manuscript.

\section{Funding}

Not applicable, there was no sources of funding for this study.

\section{Availability of data and materials}

All the data sets used for this study are available from the corresponding author and can be given with a reasonable request.

\section{Ethics approval and consent to participate}

The study was approved by the Institutional Review Board (IRB) of College of Medicine and Health Sciences at Bahir Dar University with reference number EPB/110/2017. Written permission letter was obtained from all concerned authorities. Written consents from parents of school youths were collected and verbal consent from each participant was obtained after explaining the purpose of the study. The right of participants to refuse or not to respond to questions if, they don't feel comfortable with or discontinue participation at any time was ensured. Confidentiality was kept at each step of the data collection.

\section{Consent for publication}

Not applicable.

\section{Competing interests}

The authors declare that they have no competing interests.

\section{Author details}

${ }^{1}$ Department of Reproductive Health, School of Public Health, College of Medicine and Health Sciences, Bahir-Dar University, Bahir Dar, Ethiopia. ${ }^{2}$ Department of Epidemiology and Biostatistics, School of Public Health, College of Medicine and Health Sciences, Bahir-Dar University, Bahir Dar, Ethiopia. ${ }^{3}$ Department of Epidemiology and Biostatistics, School of Public Health, College of Medicine and Health Sciences, Bahir-Dar University, Bahir Dar, Ethiopia.

Received: 11 February 2019 Accepted: 29 May 2019

Published online: 03 June 2019

\section{References}

1. Lewis J. The physiological and psychological development of the adolescent. 27:2013. http://teachersinstitute.yale.edu/curriculum/units /1991/5/91.05.07x.html. Accessed Apr 2007

2. Organization WH. Sexual health, human rights and the law. Geneva: World Health Organization; 2015.

3. Baryamutuma R, Baingana F. Sexual, reproductive health needs and rights of young people with perinatally acquired HIV in Uganda. Afr Health Sci. 2011;11(2):211-8.

4. Brown A, Jejeebhoy SJ, Shah I, Yount KM. Sexual relations among young people in developing countries: evidence from WHO case studies. Occasional Paper. 2001;4

5. Shahid $\mathrm{KH}, \mathrm{AH} \mathrm{SH}$, Wahab HA. Adolescents and premarital sex: perspectives from family ecological context. Int J Stud Child Women Elderly Disabled 2017:1

6. Abdissa B, Addisie M, Seifu W. Premarital Sexual practices, consequences and associated factors among regular undergraduate female students in
Ambo University, Oromia Regional State, Central Ethiopia, 2015. Health Sci J. 2017;11(1):1.

7. Habtamu M, Direslgne M, Hailu F. Assessment of time of sexual initiation and its associated factors among students in Northwest Ethiopia. Sci J Public Health. 2015;3(1):10-8.

8. Beyene AS, Seid AM. Prevalence of premarital sex and associated factors among out-of-school youths (aged 15-24) in Yabello town, Southern Ethiopia: a community based cross-sectional study. Pharm Innovation. 2014:3(10, Part A):10.

9. Endazenaw G, Abebe M. Assessment of premarital sexual practices and determinant factors among high school students in West Shoa Zone, Oromia Regional State, Ethiopia. Sci J Public Health. 2015;3(2):229-36.

10. Alebachew FM. The prevalence of pre-marital sexual practice and its contributing factors in robit high school students science publishing group. 2016;1(1):1-6.

11. Gage AJ, Meekers D. Sexual activity before marriage in sub-Saharan Africa. Soc Biol. 1994;41(1-2):44-60.

12. Oljira L, Berhane $Y$, Worku A. Pre-marital sexual debut and its associated factors among in-school adolescents in eastern Ethiopia. BMC Public Health. 2012;12(1):375.

13. Bogale A, Seme A. Premarital sexual practices and its predictors among in-school youths of shendi town, west Gojjam zone, North Western Ethiopia. Reprod Health. 2014;11(1):49.

14. Mulugeta $Y$, Berhane $Y$. Factors associated with pre-marital sexual debut among unmarried high school female students in bahir Dar town, Ethiopia: cross-sectional study. Reprod Health. 2014;11(1):40.

15. Desale AY, Argaw MD, Yalew AW. Prevalence and associated factors of risky sexual Behaviours among in-school youth in Lalibela town, north Wollo zone, Amhara regional sate. Ethiop Cross Sect Study Des Sci. 2016;4(1):57-64.

16. Dadi AF, Teklu FG. Risky sexual behavior and associated factors among grade 9-12 students in Humera secondary school, western zone of Tigray, NW Ethiopia, 2014. Sci J Public Health. 2014;2(5):410-6.

17. Seme A, Wirtu D. Premarital sexual practice among school adolescents in Nekemte Town, East Wollega. Ethiop J Health Dev. 2008;22(2):167-73.

18. office; Dte. Total numbers of high school students in Debretabor town. Debretabor: Debertabor Town Educaion Office; 2017.

19. Taye A, Asmare I. Prevalence of premarital sexual practice and associated factors among adolescents of Jimma Preparatory School Oromia Region, South West Ethiopia. J Nurs Care. 2016;5(2):353.

20. Seme A, Wirtu D. Premarital sexual practice among in-school adolescents in Nekemtie town. Ethiop j Health Dev. 2006;22(2):167-73.

21. Kassa GM, Woldemariam EB, Moges NA. Prevalence of premarital sexual practice and associated factors among alamata high school and preparatory school adolescents, Northern Ethiopia. Glob J Med Res 2014.

22. Rudatsikira E, Ogwell A, Siziya S, Muula A. Prevalence of sexual intercourse among school-going adolescents in Coast Province, Kenya. Tanzania J Health Res. 2007;9(3):159-65.

23. Dapaah JM, Appiah SCY, Amankwaa A, Ohene LR. Knowledge about sexual and reproductive health services and practice of what is known among Ghanaian Youth, a mixed method approach. Adv Sex Med. 2016;06(01):63086.

24. Abebe M, Tsion A, Netsanet F. Living with parents and risky sexual behaviors among preparatory school students in Jimma zone, South west Ethiopia. Afr Health Sci. 2013;13(2):498-506.

25. Kassa GM, Tsegay G, Abebe N, Bogale W, Tadesse T, Amare D, et al. Early Sexual Initiation and Associated Factors among Debre Markos University Students, North West Ethiopia. Science. 2015;4(5):80-5.

26. Oljira L, Berhane Y, Worku A. Pre-marital sexual debut and its associated factors among in-school adolescents in eastern Ethiopia. BMC Public Health. 2012;12:375.

27. Meleko A, Mitiku K, Kebede G, Muse M, Moloro N. Magnitude of Pre-marital Sexual Practice and its Associated Factors among Mizan Preparatory School Students in Mizan Aman Town, South West Ethiopia. J Community Med Health Educ. 2017;7:539. https://doi.org/10.4172/2161-0711.10005 39.

28. Kassa GM, Woldemariam EB, Moges NA. Prevalence of premarital sexual practice and associated factors among alamata high school and preparatory school adolescents, Northern Ethiopia. Glob J Med Res. 2014;14(3). 
29. Negeri EL. Assessment of risky sexual behaviors and risk perception among youths in Western Ethiopia: the influences of family and peers: a comparative cross-sectional study. BMC Public Health. 2014;14(1):301.

30. Taye A, Asmare I. Prevalence of premarital sexual practice and associated factors among adolescents of jimma preparatory school Oromia Region, South West Ethiopia. J Nurs Care. 2016. https://doi.org/10.4172/21671168.1000332

31. Tekletsadik E, Shaweno D, Daka D. Prevalence, associated risk factors and consquences of premarital sex among female students in aletawondo highschool, Sidama zone, Ethiopia. J Public Health Epidemiol. 2014;6(7):216-22

\section{Publisher's Note}

Springer Nature remains neutral with regard to jurisdictional claims in published maps and institutional affiliations.
Ready to submit your research? Choose BMC and benefit from:

- fast, convenient online submission

- thorough peer review by experienced researchers in your field

- rapid publication on acceptance

- support for research data, including large and complex data types

- gold Open Access which fosters wider collaboration and increased citations

- maximum visibility for your research: over $100 \mathrm{M}$ website views per year

At BMC, research is always in progress.

Learn more biomedcentral.com/submissions 